\title{
Phenolic Constituents from the Tree Barks of Garcinia cf cymosa and their Antioxidant and Antibacterial Activities
}

\author{
Yuliar $^{1}$, Yunazar Manjang ${ }^{1, *}$, Sanusi Ibrahim ${ }^{1}$ and Sjamsul Arifin Achmad ${ }^{2}$ \\ ${ }^{1}$ Department of Chemistry, Faculty of Mathematic and Natural Sciences, Andalas University, Padang 25163, West Sumatera, Indonesia \\ ${ }^{2}$ Department of Chemistry, Faculty of Mathematic and Natural Sciences, Institut Teknologi Bandung, Bandung 40132, Indonesia \\ Received 10 January 2013, Revised 22 March 2013, Accepted 29 March 2013, Available online 18 April 2013
}

\begin{abstract}
Two isoprenylated xanthones, $\alpha$-mangostin (1) and $\beta$-mangostin (2) were isolated from the tree barks of Garcinia cf cymosa, along with the flavanol epicatechin (3). Their structures were elucidated by analysis of spectroscopic data. Compounds 1-3 exhibited moderate in vitro antibacterial activity against Staphylococcus aureus and Bacillus sp, while in the 1,2-diphenyl-picryl-hydrazyl (DPPH) antioxidant assay system only compound 3 showed moderate free radical scavenging activity, with IC50 value of 41.8 ppm.
\end{abstract}

| Antibacterial | antioxidant | flavanol | Garcinia cf cymosa | xanthones |

(B) 2013 Ibnu Sina Institute. All rights reserved. http://dx.doi.org/10.11113/mjfas.v9n3.94

\section{INTRODUCTION}

The genus Garcinia (Clusiaceae or Guttiferae) comprises about 200 species and occurs in moist tropical regions, including Southeast Asia [1,2]. Phytochemical investigations have shown that this group of plants, such as Garcinia mangostana, are very rich inphenolic compound, prenylated xanthones and flavonoids [3,4]. Biological studies on the constituents of the fruits of $G$. mangostana demonstrated antibacterial, antifungal, antitumor promotion, and other biological activities [3,5,6]. The present work on the tree barks of Garcinia cf cymosa collected from Muarobungo District, Jambi Province, Sumatra, Indonesia was investigated for the first time to evaluate the phytochemical profil of this endemic plant in comparison with that of other related species. This preliminary investigation led to the isolation of two prenylated xanthones, namely, $\alpha$-mangostin (1) [7-9] and $\beta$-mangostin (2) $[10,11]$ along with a flavanol epicatechin (3) [4]. The structural characterization, as well as antioxidant and antibacterial evaluation of these compounds against Escherichia coli, Staphylococcus aureus and Bacillus sp, are discussed herein.

\section{EXPERIMENTAL SECTION}

General Experimental Procedures. Melting points were determined using a Fisher Jhone micromelting point apparatus and are uncorrected. Ultraviolet (UV) spectra were recorded on a UV-Vis spectrophotometer 1700 Series in $\mathrm{MeOH}$ and infrared (IR) spectra on a Perkin Elmer 1600 Series. spectrophotometer in $\mathrm{CHCl}_{3}$. The ${ }^{1} \mathrm{H}$ and ${ }^{13} \mathrm{C} \mathrm{NMR}$,
COSY, HMQC, and HMBC were run on JEOL JNM-ECS 400 spectrometers. All mass spectra were taken under high resolution time of flight mass spectrum (HRTOFMS) conditions with Waters PremierXE spectrometer. Thin layer chromatography (TLC) was done on $\mathrm{GF}_{254}$ (Merck).

Plant Material. Garcinia cf cymosa was collected in Juni 2011 from the region of Muarobungo District, Jambi Province, Indonesia, and authenticated by the Herbarium Bogoriensis, Indonesian Institute of Sciences, Cibinong, Bogor, Indonesia. A voucher speciment has been deposited at the Herbarium.

Extraction and Separation. The air-dried powdered tree barks of Garcinia cf cymosa (5 kg) were exhaustively macerated with $\mathrm{MeOH}$ at room temperature, and concentrated to give a dark brown crude extract (647 g). Part of the $\mathrm{MeOH}$ extract (200 g) was successively fractionated by column chromatography on silica gel and eluted with a gradient of $n$-hexane and dichloromethane, and then ethyl acetate to obtain 15.2, 21.4, and $38.7 \mathrm{~g}$ of the respective residues after evaporating the solvents.

Part of the n-hexane extract $(10$ g) was chromatogtaphed on silica gel and eluted with $n$-hexane, dichloromethane, ethyl acetat, and methanol to obtain 8 major fractions. Fraction 3 (1.47 g) was purified on silica column to yield 124 vials, and vial 39 on crystalization gave pure $\alpha$-mangostin (1) (45 mg). Part of the dichloromethane extract (6.5 g) was also submitted to silica column chromatography using $n$-hexane, dichloromethane, etil asetat, and methanol as eluents to produce 15 major fractions. Fraction 11 (0.8 g) under the same conditions yielded $\beta$-mangostin (2) (268 mg). Part of the ethyl asetate extract (10 g) was submitted to chromatographic separation 
on silica column to give 21 major fractions. Fraction $3(0.2$ g) under similar conditions yielded epicatechin (3) (22 mg).

\section{RESULTS AND DISCUSSIONS}

The dried powder of tree barks of Garcinia $c f$ cymosa were macerated with methanol at room temperature and the dried residue obtained was then separated with column chromatography to afford two prenylated xanthones, $\alpha$-mangostin (1) and $\beta$-mangostin (2), together with a flavanol, epicatechin (3).

$\boldsymbol{\alpha}$-Mangostin (1), was isolated as a yellow powder, with mp. 193-194 ${ }^{\circ} \mathrm{C}$. The molecular formula $\mathrm{C}_{24} \mathrm{H}_{26} \mathrm{O}_{6}$ $(\mathrm{m} / \mathrm{z}$ 410,1709) was determined by high resolution time of flight mass spectrum (HRTOFMS), the UV ( $\lambda_{\max } 244,258$, $314 \mathrm{~nm}$ ) and IR spectra were indicative of a xanthone derivative. The ${ }^{1} \mathrm{H}$ NMR spectrum showed two aromatic singlets $[\delta 6.29(1 \mathrm{H}, \mathrm{s})$ and $6.83(1 \mathrm{H}, \mathrm{s})]$, and one methoxyl group $[\delta 3.80$ (3H. s)]. Signals due to two prenyl groups were also observed at $[\delta 1.77(3 \mathrm{H}, \mathrm{s})$ and $1.83(3 \mathrm{H}, \mathrm{s}), 3.45$ $(2 \mathrm{H}, \mathrm{d}, J=6.1 \mathrm{~Hz}), 5.26(1 \mathrm{H}, \mathrm{m})]$, and $[\delta 1.59(3 \mathrm{H}, \mathrm{s})$, 1.84 (3H, s), 4,09 ( $2 \mathrm{H}, \mathrm{d}, J=6.1 \mathrm{~Hz}$ ), 5.29 (1H, m)], The ${ }^{1} \mathrm{H}$ and ${ }^{13} \mathrm{C}$ NMR spectral data of $\mathbf{1}$ closely resembled those of $\alpha$-mangostin reported in the literature ${ }^{7}$ (Table 1 ). The structural assignments were substantiated by 2D NMR techniques HMQC and HMBC. In the HMBC spectrum the proton resonating at $[\delta 3.45, \mathrm{H}-11]$ showed long-range heteronuclear connectivities with C-1 ( $\delta$ 160.7), C-2 $(\delta$ 111.8 ), and C-3 ( $\delta$ 154,6). While, the proton $\mathrm{H}-16$, resonating at $\delta 4.09$, exhibited $\mathrm{HMBC}$ interactions with $\mathrm{C}-7$ $(\delta 142.6), \mathrm{C}-8(\delta 137.1)$ and $\mathrm{C}-8 \mathrm{a}(\delta 112.3)$. In addition, the methoxyl signal at $\delta 3.80$ showed a cross peak with a quaternary aromatic carbon signal at $\delta 142.6$ (C-7). Thus, the observed NMR signals are characteristic of a 1,3,6,7tetraoxygenated xanthone with methoxyl and prenyl moieties at C-7, C-2 and C-8, respectively. Therefore, compound $\mathbf{1}$ may be assigned as 1,3,6-trihydroxy-2,8diprenyl-7-methoxyxanthone, known as $\alpha$-mangostin.

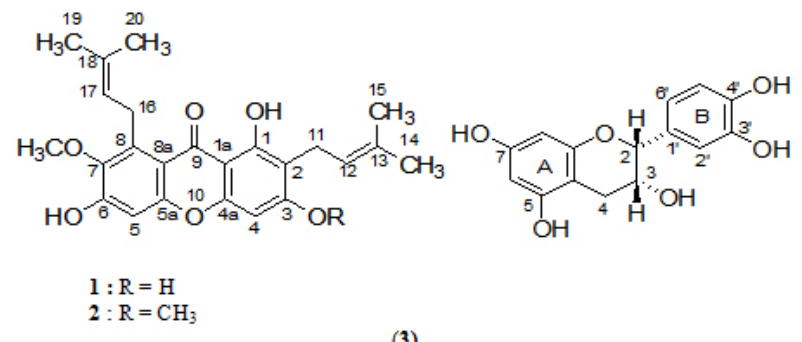

(3)

$\boldsymbol{\beta}$-Mangostin (2), was obtained as a yellow powder, mp. $184-185{ }^{\circ} \mathrm{C}$, and HRTOFMS spectrum at $\mathrm{m} / \mathrm{z} 424.1855$ established a molecular formula of $\mathrm{C}_{25} \mathrm{H}_{28} \mathrm{O}_{6}$. Its ultraviolet (UV) spectrum, posessing characteristic absorption maxima ( $\lambda_{\text {maks }} 243,258,316,319 \mathrm{~nm}$ ) suggesting that 2 also possessed a xanthone skeleton. The ${ }^{1} \mathrm{H}$ NMR spectrum of $\mathbf{2}$ showed signals for two aromatic protons at $[\delta 6.48(1 \mathrm{H}, \mathrm{s})$ and $6.84(1 \mathrm{H}, \mathrm{s})]$, along with two methoxyl groups at $[\delta$ $3.96(3 \mathrm{H}, \mathrm{s})$ and $3.80(3 \mathrm{H}, \mathrm{s})]$. The ${ }^{1} \mathrm{H}$ NMR spectrum of 2 also indicated the presence of four methyl groups on vinyl carbon $[\delta 1.77(3 \mathrm{H}, \mathrm{s}), 1.83(3 \mathrm{H}, \mathrm{s}), 1.59(3 \mathrm{H}, \mathrm{s})$ and 1.84 $(3 \mathrm{H}, \mathrm{s})]$, along with two benzylic methylenes $[\delta 3.31(2 \mathrm{H}, \mathrm{d})$ and $4.12(2 \mathrm{H}, \mathrm{d})]$ and two olefinic methines at $[\delta 5,26(1 \mathrm{H}$, $\mathrm{m})$ and $5,29(1 \mathrm{H}, \mathrm{m})]$ indicative for the presence of two prenyl side chains. The ${ }^{1} \mathrm{H}$ and ${ }^{13} \mathrm{C}$ NMR spectral data of $\mathbf{2}$ were similar to those reported in the literature for $\beta$ mangostin [11,12] (Table 2). The structural assignment was confirmed by 2D NMR techniques HMQC and HMBC. The most important observations in the HMBC spectrum were the connectivities observed between the singlet proton signals of benzylic methylene signals at C-11 and C-16.The proton resonating at $[\delta 4.12, \mathrm{H}-11]$ showed long-range heteronuclear connectivities with C-1 $(\delta$ 160.1), C-2 $(\delta$ $111.6)$, and C-3 $(\delta 164,4)$. While, the H-16, resonating at $\delta 3.31$ exhibited HMBC interactions with C-7 ( $\delta$ 144.4), C8 ( $\delta$ 138.0) and C-8a $(\delta$ 111.9). In addition, the methoxyl signal at $\delta 3.80$ and 3.93 showed cross peaks with quaternary aromatic carbon signals at $\delta 144.4$ (C-7) and 164.4 (C-3), respectively. Thus, the structure of compound 2 was therefore concluded to be 1,6-dihydroxy-3,7dimethoxy-2,8-diprenylxanthone known as $\beta$-mangostin.

\begin{tabular}{|c|c|c|c|c|c|}
\hline \multirow{2}{*}{$\mathrm{C}$} & \multicolumn{2}{|c|}{${ }^{13} \mathrm{C}-\mathrm{NMR}$ (ppm) } & \multirow{2}{*}{ H } & \multicolumn{2}{|c|}{${ }^{1} \mathrm{H}-\mathrm{NMR}(\mathrm{ppm})$} \\
\hline & Compound I & $\alpha$-Mangostin & & Compound 1 & $\alpha$-Mangostin \\
\hline 1 & 160,7 & 161,7 & & & \\
\hline 2 & 111,8 & 111,1 & & & \\
\hline 3 & 154,6 & 155,7 & & & \\
\hline 4 & 93,4 & 93,2 & 4 & 6,29 & 6,38 \\
\hline $4 a$ & 161,7 & 162,9 & & & \\
\hline $5 a$ & 155,9 & 157,3 & & & \\
\hline 5 & 101,6 & 102,7 & 5 & 6.83 & 6,80 \\
\hline 6 & 155,2 & 156,2 & & & \\
\hline 7 & 142,6 & 144,5 & & & \\
\hline 8 & 137,1 & 138,1 & & & \\
\hline $8 a$ & 112,3 & 112,0 & & & \\
\hline 9 & 182,1 & 182,8 & & & \\
\hline $1 \mathbf{a}$ & 103,7 & 103,6 & & & \\
\hline 16 & 26,7 & 26,9 & 16 & 4,09 & 4,12 \\
\hline 17 & 123,2 & 124,8 & 17 & 5,29 & 5,27 \\
\hline 18 & 136,0 & 131,4 & & & \\
\hline 19 & 18,3 & 18,3 & 19 & 1,84 & 1,82 \\
\hline 20 & 25,8 & 25,9 & 20 & 1,69 & 1,64 \\
\hline 11 & 21,5 & 22,0 & 11 & 3,45 & 3,34 \\
\hline 12 & 121,5 & 124,8 & 12 & 5,26 & 5,27 \\
\hline 13 & 132,3 & 131,4 & & & \\
\hline 14 & 18,0 & 17,9 & 14 & 1,77 & 1,77 \\
\hline 15 & 25,9 & 25,8 & 15 & 1,83 & 1,63 \\
\hline $7-\mathrm{OCH}_{3}$ & 62,2 & 61,3 & $7-\mathrm{CH}_{3}$ & 3,80 & 3,78 \\
\hline
\end{tabular}

Epicatechin (3), was successfully isolated as a white powder, mp. 248-249 ${ }^{\circ} \mathrm{C}$, HRTOFMS spectrum at $\mathrm{m} / \mathrm{z}$ 290.1027 established a molecular formula of $\mathrm{C}_{15} \mathrm{H}_{14} \mathrm{O}_{6}$, and infrared (IR) spectrum, possesed characteristic absorptions for hydroxyl group (3417 $\mathrm{cm}^{-1}$ ) and an aromatic ring (1514 $\mathrm{cm}^{-1}$ ) for a phenolic compound. Analysis of ${ }^{13} \mathrm{C} \mathrm{NMR}$ spectrum revealed the presence of two aromatic rings, together with two oxymethine groups ( $\delta 66.8$ and 79.3$)$ and a methylene group ( $\delta$ 29.6) indicative for the presence of $\mathrm{CH}(\mathrm{O}-) \mathrm{CH}(\mathrm{O}-)-\mathrm{CH}_{2}$ - moiety. Therefore, compound $\mathbf{3}$ could be proposed as a flavan-3-ol. The ${ }^{1} \mathrm{H}$ NMR spectrum 
of 3 showed the presence of signals for an ABX aromatics system of ring $\mathrm{B}[\delta 6.78(1 \mathrm{H}, \mathrm{d}, J=8.3 \mathrm{~Hz}), 6.83(1 \mathrm{H}$, dd, $J$ $=2.0,8.3 \mathrm{~Hz}), 7.05(1 \mathrm{H}, \mathrm{d}, J=1.4 \mathrm{~Hz})$ and two broad singlets for two meta oriented aromatic protons of ring $\mathrm{A}[\delta$ $6,02(1 \mathrm{H}, \mathrm{d}, J=2,2 \mathrm{~Hz}, \mathrm{H}-6)$ and 5,92 (1H, d, $J=2,2 \mathrm{~Hz}$, $\mathrm{H}-8)$. Furthermore, by COSY and HMBC correlations, the signals observed at $4.87 \mathrm{ppm}$ (brs), 4.20 (brs), $2.92 \mathrm{ppm}$ (dd, $J=5.5,4.8 \mathrm{~Hz}$ ) and $2.54 \mathrm{ppm}(\mathrm{dd}, 8.3,8.9 \mathrm{~Hz}$ ) were assigned as $\mathrm{H}-2, \mathrm{H}-3, \mathrm{H}-4 \mathrm{a}$, and $\mathrm{H}-4 \mathrm{~b}$, respectively. Taking note on the coupling constants for $\mathrm{H}-2, \mathrm{H}-3$ and $\mathrm{H}-4$, the relative stereochemistry of the phenyl group at $\mathrm{C}-2$ and hydroxyl group at C-3 were both as alpha $(\alpha)$. Accordingly the structure of compound $\mathbf{3}$ was established as $(2 \mathrm{~S}, 3 \mathrm{~S})$ 3,5,7,3',4'-pentahydroxyflavan known as epicatechin. The ${ }^{1} \mathrm{H}$ and ${ }^{13} \mathrm{C}$ NMR spectral data of $\mathbf{3}$ (Table 3 ) also closely resembled those of epicatechin reported in the literature ${ }^{4}$.

\begin{tabular}{|c|c|c|c|c|c|}
\hline \multirow{2}{*}{ C } & \multicolumn{2}{|c|}{${ }^{13} \mathrm{C}-\mathrm{NMR}$ (ppm) } & \multirow{2}{*}{$\mathrm{H}$} & \multicolumn{2}{|c|}{${ }^{1} \mathrm{H}-\mathrm{NMR}$ (ppm) } \\
\hline & Compound 2 & $\beta$-mangostin & & Compound 2 & $\beta$-mangostin \\
\hline 1 & 160,1 & 160,6 & & & \\
\hline 2 & 111,6 & 111,1 & & & \\
\hline 3 & 164,4 & 162,9 & & & \\
\hline 4 & 89,7 & 89,9 & 4 & 6,48 & 6,36 \\
\hline $4 a$ & 156,1 & 155,7 & & & \\
\hline $5 a$ & 157,4 & 157,3 & & & \\
\hline 5 & 102,5 & 102,7 & 5 & 6.84 & 6,39 \\
\hline 6 & 156,2 & 156,2 & & & \\
\hline 7 & 144,4 & 144,5 & & & \\
\hline 8 & 138,0 & 138,1 & & & \\
\hline $8 a$ & 111,9 & 112,2 & & & \\
\hline 9 & 182,7 & 182,8 & & & \\
\hline $1 \mathrm{a}$ & 104,0 & 103,6 & & & \\
\hline 16 & 21,8 & 21,9 & 16 & 3,31 & 3,34 \\
\hline 17 & 124,6 & 123,5 & 17 & 5,20 & 5,27 \\
\hline 18 & 131,4 & 132,4 & & & \\
\hline 19 & 17,8 & 17,9 & 19 & 1,63 & 1.63 \\
\hline 20 & 25,8 & 25,9 & 20 & 1,77 & 1,77 \\
\hline 11 & 26,8 & 26,9 & 11 & 4,12 & 4,12 \\
\hline 12 & 123,2 & 123,32 & 12 & 5,27 & 5,27 \\
\hline 13 & 131,3 & 131,4 & & & \\
\hline 14 & 18,2 & 18,3 & 14 & 1,65 & 1,69 \\
\hline 15 & 25,9 & 25,9 & 15 & 1,83 & 1,82 \\
\hline $3-\mathrm{OCH}_{3}$ & 56,4 & 56,5 & $3-\mathrm{OCH}_{3}$ & 3,96 & 3,93 \\
\hline $7-\mathrm{OCH}_{3}$ & 62,2 & 61,3 & $7-\mathrm{OCH}_{3}$ & 3,80 & 3,83 \\
\hline
\end{tabular}

Antibacterial Activity. The isolated compounds, $\alpha$-mangostin (1), $\beta$-mangostin (2), and epicatechin (3) were evaluated for their antimicrobial activities against Escherichia coli, Staphylococcus aureus, and Bacillus sp. using disk-diffusion method. Zone of inhibition was determined after incubation at $37{ }^{\circ} \mathrm{C}$ for $48 \mathrm{~h}$. Zone diameter of each compounds against E. coli, S. aureus, and Bacillus sp. are tabulated in Table 4. The data indicated that $\alpha$-mangostin (1), showed high antibacterial activity against $S$. aureus and Bacillus sp. by producing zone of inhibitions of 3.4 and $3.2 \mathrm{~mm}$, respectively, greater than that of chloramphenicol as a standard, with a zone of inhibitions of 2.6 - $2.7 \mathrm{~mm}$. However, $\alpha$-mangostin (1) showed very low activity against $E$. coli compared to standard. $\beta$-Mangostin (2) also showed similar tendency, but with higher antibacterial effects with 6.3 and $5.0 \mathrm{~mm}$ of zone inhibiition, respectively against $S$. aureus and Bacillus sp. On the other hand, compound $\mathbf{3}$ showed only antibacterial activity against Bacillus sp.
Antioxidant activity. DPPH radical scavenging assay was used to evaluate the antioxtdant activity of the isolated compoumds 1-3, and the results were compared with that of ascorbic acid as a standard. The data obtained (see Table 5). Indicated that $\alpha$-mangostin (1) and $\beta$-mangostin (2) shown no antioxidant activity with, IC $_{50} 566,6$ and 250,5 ppm, respectively, while epicatechin (3) is moderately active, with $\mathrm{IC}_{50} 41.8 \mathrm{ppm}$. These results indicated that the phenolic constituents obtained from polar fraction was responsible for the antioxidant phenomena.

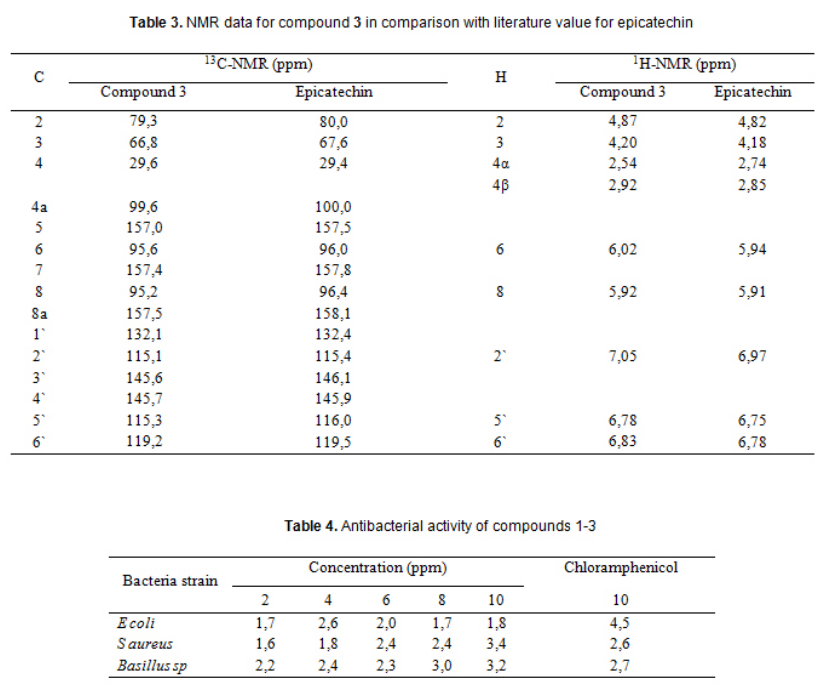

$\boldsymbol{\alpha}$-Mangostin (1): yellow powder; mp. 193-194 ${ }^{\circ} \mathrm{C}$; HRTOFMS $\mathrm{m} / \mathrm{z} \quad 410.1709$ (calcd for $\mathrm{C}_{24} \mathrm{H}_{26} \mathrm{O}_{6} \mathrm{~m} / \mathrm{z}$ 410.17.29); UV (EtOH) ( $\lambda_{\max }$ 243, 258, 314, 319 nm; IR

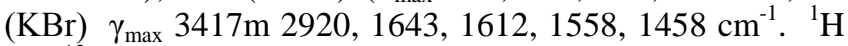
and ${ }^{13} \mathrm{C}$ NMR data (see Table 1 )

及-Mangostin (2): light yellow powder; mp. 184-185 ${ }^{\circ} \mathrm{C}$; HRTOFMS $\mathrm{m} / \mathrm{z} 424.1855$ (calcd for $\mathrm{C}_{25} \mathrm{H}_{28} \mathrm{O}_{6} \mathrm{~m} / \mathrm{z}$ 424.1855); UV (EtOH) ( $\lambda_{\max } 243,258,316,319 \mathrm{~nm}$; IR (KBr) $\gamma_{\max }$ 3398. 2993, 2924, 2858, 1647, 1600, 1558, 1427 $\mathrm{cm}^{-1}$. ${ }^{1} \mathrm{H}$ and ${ }^{13} \mathrm{C}$ NMR data (see Table 2).

Epicatechin (3): white powder; mp. $248-249{ }^{\circ} \mathrm{C}$; HRTOFMS $\mathrm{m} / \mathrm{z} 290.1027$ (calcd for $\mathrm{C}_{15} \mathrm{H}_{14} \mathrm{O}_{6} \mathrm{~m} / \mathrm{z}$ 290.0790); UV (EtOH) ( $\lambda_{\max } 243,258,316,319 \mathrm{~nm}$; IR (KBr) $\gamma_{\max }$ 3417. 2962, 2920, 2854, 1643, 1612, 1558, 1458, $1076 \mathrm{~cm}^{-1}$. ${ }^{1} \mathrm{H}$ and ${ }^{13} \mathrm{C}$ NMR data (see Table 3 ).

Table 5. Antioxidant activity of compounds 1-3

\begin{tabular}{cccc}
\hline Compounds & Regression & $\mathrm{R}$ & $\mathrm{IC}_{50}(\mathrm{ppm})$ \\
\hline $1(\mathrm{Y} 1)$ & $\mathrm{Y}=0,0087 \mathrm{x}+0,701$ & 0,937 & 566,6 \\
$2(\mathrm{Y} 2)$ & $\mathrm{Y}=0,195 \mathrm{x}+1,142$ & 0,958 & 250,5 \\
$3(\mathrm{Y} 3)$ & $\mathrm{Y}=0,917 \mathrm{x}+11,64$ & 0,925 & 41,8 \\
\hline
\end{tabular}

Antibacterial and Antioxidant Activities. The isolated compounds, $\alpha$-mangostin (1), $\beta$-mangostin (2), and epicatechin (3) were evaluated for their antimicrobial activities against Escherichia coli, Staphylococcus aureus, and Bacillus sp. using disk-diffusion method. Zone of 
inhibition was determined after incubation at $37{ }^{\circ} \mathrm{C}$ for 48 hr and compared to that of chloramphenicol as the standard. For zone diameters of each isolated compounds 1-3 against E. coli, S. aureus, and Bacillus sp. (see Table 4). DPPH radical scavenging assay were used to evaluate the scavenging ability of radicals in vitro by solutions of compoumds 1-3 (50 $\mu \mathrm{M})$ in $\mathrm{MeOH}(450 \mathrm{ml})$ and the final absorbance was recorded on microplate reader at $516 \mathrm{~nm}$. The results were tabulated and compared with that of ascorbic acid as a standard (see Table 5).

\section{ACKOWLEDGEMENT}

We are grateful to the Herbarium Bogoriensis, Indonesian Institute of Sciences (LIPI), Cibinong, Bogor, Indonesia, for identification of the plant, and to Dr. Morina Adfa Bengkulu University)for recording the NMR spectra.

\section{REFERENCES}

[1] A. Cronquist, An Integrated System of Classification of Flowering Plants, Columbia University Press, New York, 1981, 337-340.
[2] L. M. Perry, Medicinal Plants of East and Southeast Asia, The MIT Press, Massachusetts, 1980, 174-175

[3] S. A. Achmad, E. H. Hakim, L. Makmur, Y. M. Syah, D. Juliawaty, Mujahidin, Chemistry and Uses of Indonesian Medinal Plants, ITB Publisher, 2010, 147-164.

[4] S. Suksamrarn, N. Suwannapoch, P. Ratananukul, N. Aroonlerk, A. Suksamrarn, J. Nat. Prod., 65 (2002) 761-763.

[5] S. Suksamrarn, N. Suwannapoch, W. Phakhodee, J. Thanuhiranlert, P. Ratananukul, N. Chimnoi, A. Suksamrarn, Chem. Pherm. Bull, 51 (2003) 857-859.

[6] S. Suksamram, O. Komutiban, P. Ratananukul, N. Chimnoi, N. Nartpommatulee, A. Suksamram, Chem. Pherm. Bull, 54 (20060 301-305.

[7] S. X. Chen, M. Wan, B. N. Loh, Planta Med, 62 (1996) 381-382.

[8] P. Yates, G. H. Stout, J. Amer. Chem. Soc., 80 (1958) 1691-1700.

[9] A. Jefferson, A. J. Quillinan, F. Scheinmann, K. Y. Sim, Aust. J. Chem., 23 (1970) 2539-2543.

[10] P. Yates, H. B. Bhat, Structure of $\beta$-mangostin, Canadian J, Chem., 46 (1968) 3770-3772.

[11] T. R. Govindachari, P. S. Kalyanaraman, N. Muthukumaraswamy, B. R. Pai, Tetrahedron, 27 (1971) 3919-3926.

[12] Lukis, Indo. J. Chem., 9 (2009) 321-327. 